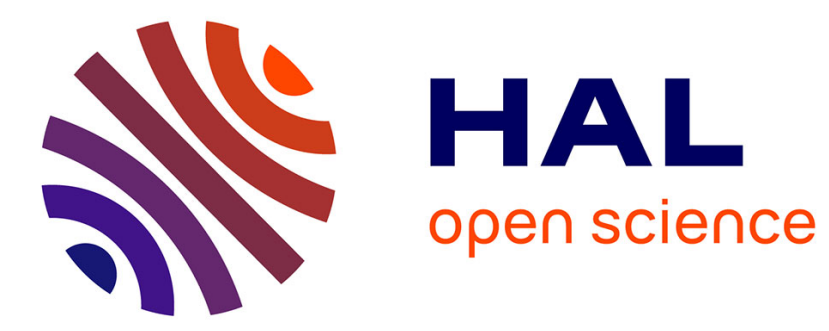

\title{
Impact of Temperature Variations on the Hydro-Mechanical Parameters of a Sensitive Soil
}

Hossein Eslami, S. Rosin-Paumier, Adel Abdallah, Farimah Masrouri

\section{To cite this version:}

Hossein Eslami, S. Rosin-Paumier, Adel Abdallah, Farimah Masrouri. Impact of Temperature Variations on the Hydro-Mechanical Parameters of a Sensitive Soil. Geo-Chicago 2016, Aug 2016, Chicago, France. 10.1061/9780784480137.007 . hal-01817516

\section{HAL Id: hal-01817516 https://hal.science/hal-01817516}

Submitted on 18 Jun 2018

HAL is a multi-disciplinary open access archive for the deposit and dissemination of scientific research documents, whether they are published or not. The documents may come from teaching and research institutions in France or abroad, or from public or private research centers.
L'archive ouverte pluridisciplinaire $\mathbf{H A L}$, est destinée au dépôt et à la diffusion de documents scientifiques de niveau recherche, publiés ou non, émanant des établissements d'enseignement et de recherche français ou étrangers, des laboratoires publics ou privés. 


\title{
Impact of temperature variations on hydro-mechanical parameters of a sensitive soil
}

\author{
Hossein Eslami ${ }^{1,2}$, Sandrine Rosin ${ }^{1}$, Adel Abdallah ${ }^{1}$ and Farimah Masrouri ${ }^{1}$
}

${ }^{1}$ LEMTA (CNRS, UMR 7563), Université de Lorraine, Vandœuvre-lès-Nancy, France ${ }^{2}$ ESITC de Metz, Metz, France

\begin{abstract}
The incorporation of heat exchangers in geostructures produces a cyclic variation of the temperature in the adjacent soil. Therefore, there are important questions about the effect of temperature variations on hydro-mechanical soil parameters. In this study, mini-pressuremeter tests were conducted in laboratory on a homogeneous material submitted to different thermal loading ( 1 to $40{ }^{\circ} \mathrm{C}$ ). The tested material, an illitic soil, is compacted in a thermo-regulated container with $0.6 \mathrm{~m}$ diameter and $0.8 \mathrm{~m}$ height, at optimal water content $(31.3 \%)$ and $90 \%$ of maximum dry density $\left(1.29 \mathrm{Mg} / \mathrm{m}^{3}\right)$. Only six tests are performed in each container to prevent edge effects and the influence between the tests. The impact of temperature variation on creep pressure $\left(p_{f}\right)$, limit pressure $\left(p_{l}\right)$ and pressuremeter modulus $\left(E_{p}\right)$ were determined. A decrease in creep pressure and limit pressure with increasing temperature was observed, while the variation of pressuremeter modulus was less pronounced. The first cycle induced more important parameter variations than the subsequent cycles.
\end{abstract}

\section{INTRODUCTION}

The incorporation of heat exchangers in geostructures leads to a temperature variation in the adjacent soil over a range from 4 to $30^{\circ} \mathrm{C}$ (Knellwolf et al., 2011). Consequently, there are important questions about the effect of temperature variations on hydromechanical soil properties and load transfer in the pile.

In the case of energy piles, on one hand, the thermal expansion or contraction causes additional thermal stresses in the pile, which can influence the skin friction and end bearing and consequently the load transfer (Bourne-Webb et al., 2013; Olgun et al., 2015). On the other hand, the cyclic thermal variation of the soil may affect its hydromechanical properties. Thus, the behavior of an energy pile is directly related to the coupling of thermal, hydraulic and mechanical phenomena. 
Various studies on the behavior of energy piles and their thermo-mechanical response have been conducted in-situ (Laloui et al., 2003; Bourne-Webb et al., 2009; Akrouch et al., 2014; Murphy and McCartney, 2015) and in the laboratory (Stewart and McCartney, 2013; Tang et al., 2013). All these studies have focused on pile behaviour. The effect of temperature variations on the soil parameters has been neglected despite the potentially important effect of cyclic temperature variations on shear strength, yielding and criticalstate soil properties. In particular, the contraction of the elastic domain (i.e., the yield locus) with increasing temperature has been demonstrated for various clay materials (Hueckel and Baldi 1990; Tanaka et al., 1997; Graham et al., 2001; Cekerevac and Laloui 2004; Marques et al., 2004; Uchaipichat and Khalili 2009). The calculation of the bearing capacity of deep foundations is actually based on pressuremeter or/and penetrometer test results (AFNOR, 2012). Eslami et al. (2015) studied the effect of temperature variation on penetration test parameters in two compacted soils. However, no data are available on the effect of temperature on pressuremeter parameters. In this study, the mini-pressuremeter tests were conducted in laboratory on a soil submitted to different thermal loading $\left(1\right.$ to $40{ }^{\circ} \mathrm{C}$ ) to quantify the temperature effect on the mechanical behavior of the soil.

In the following sections, the material and the developed experimental device are first described. Then, the results are detailed and the impact of thermal variations on the pressuremeter parameters is discussed.

\section{MATERIAL AND METHOD}

In this part, the studied material is first presented, then experimental device is described and finally the mini-pressuremeter tests are detailed.

\section{Basic characterization of the material}

The tested material is an illitic soil named Arginotech ${ }^{\circledR}$ that contains $77 \%$ illite, $10 \%$ kaolinite, $12 \%$ calcite and traces of quartz and feldspar according to the furnisher. Minipenetration tests, conducted on this soil by Eslami et al. (2015) showed the sensitivity of this material to temperature variations.

The particle-size distribution of the soil was determined using a laser Malvern Mastersizer 2000® device (Figure 1a). Almost 85\% of the particles of the illitic material are smaller than $0.002 \mathrm{~mm}$ (clay particles). The liquid limit (LL), plastic limit (PL) and plasticity index (PI) are 65\%, 34\%, and 31\% respectively (AFNOR, 1993). A optimum water content of $31.3 \%$ and a maximum dry density of $1.43 \mathrm{Mg} / \mathrm{m}^{3}$ are obtained from the standard Proctor curve for the material (AFNOR, 1999) (Figure 1b). 

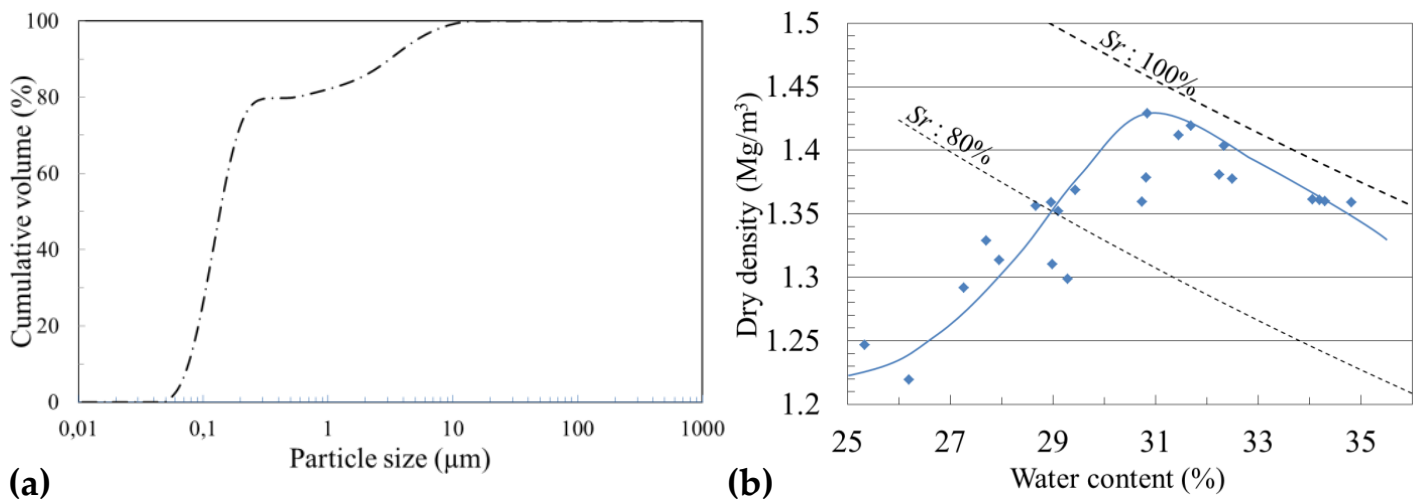

\section{FIG. 1. Characteristic of the studied illitic soil: a) particle size distribution and b) Compaction curve, $S_{r}$ : The degree of saturation.}

\section{Experimental device and methods}

To perform mini-pressuremeter tests under controlled temperature, a homogeneous massif with a large volume is required as well as an experimental device to impose thermal variations to the massif. In this part, the developed methodology to obtain a meter-scale sample with homogeneous properties (temperature, water content and dry density) is described.

First, the required amount of water was added to the material $\left(w_{\text {initial }} \approx 17 \%\right)$ in a large capacity fixed-speed $(38 \mathrm{rpm})$ mixer (MIX120®) to reach the target water content: $\mathrm{w}_{\mathrm{OPN}}=31.3 \%$. The wet material is stored in 8 plastic drums for a minimum of 5 days to ensure good homogenization. A pneumatic compactor is used to compact the material in a cylindrical stainless steel container of $800 \mathrm{~mm}$ in height and $600 \mathrm{~mm}$ in diameter (Figure 2a). The compactor applied dynamic forces on a metallic plate of $4 \mathrm{~mm}$ in thick and $600 \mathrm{~mm}$ in diameter to facilitate a homogeneous compaction of the soil. The results of the preliminary series lead to the choice of a compaction in 11 70-mm-thick layers.

A stainless steel tube welded to the outside of the container was connected to a Vulcatherm ${ }^{\circledR}$ thermoregulator to facilitate the circulation of an ethylene glycol-water solution at the target temperature $\left(-20\right.$ to $\left.90{ }^{\circ} \mathrm{C}\right)$ in the tube. Thus, the soil compacted in the container is heated or cooled by the container's outer lateral surface. Insulating sleeves were placed around the tube to reduce the heat exchange with the surrounding atmosphere. The top of the massif was insulated with a plastic film to preserve the initial water content. Finally, the entire device was placed in a box constructed of 40-mm-thick extruded polystyrene plates to reinforce the insulation. Figure $2 \mathrm{~b}$ shows the total parts of the developed experimental device in order to perform the mini-pressuremeter tests.

Seven thermal sensors PT100 are positioned within the massif at various depths and various distances from the wall of the container. The sensors are plugged to a data logger in order to monitor the temperature evolution inside the compacted soil during the temperature variations. 


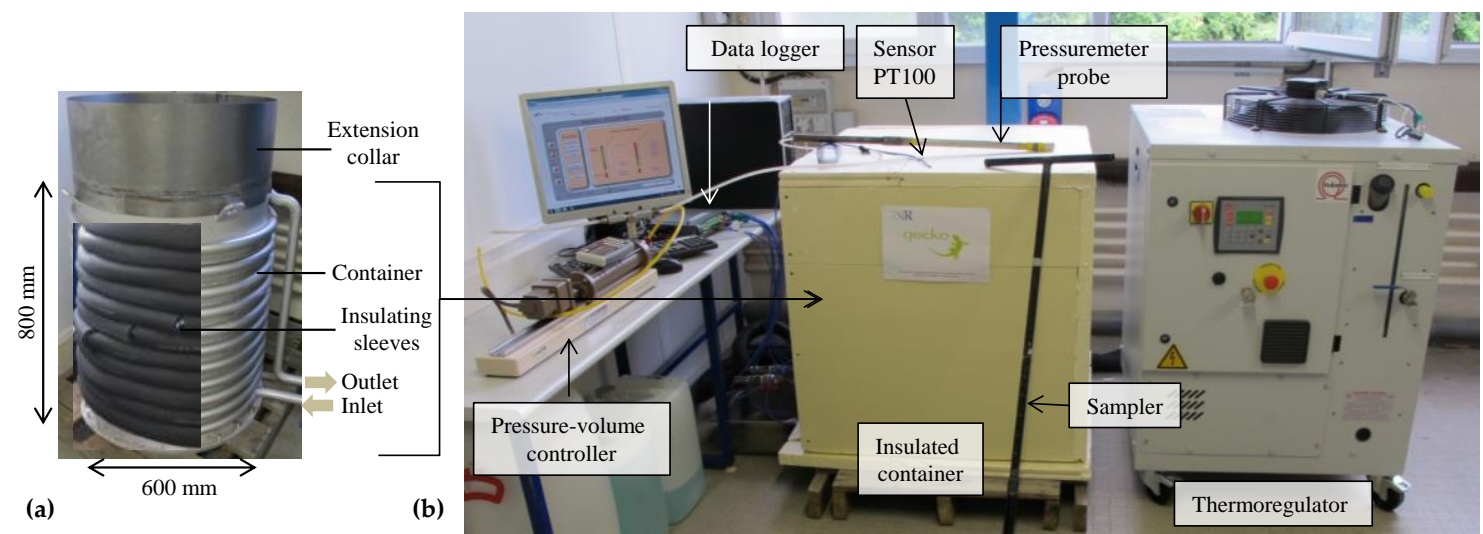

FIG. 2. (a) Thermo-regulated metric scale container; (b) Total parts of developed experimental device.

\section{Mini-pressuremeter tests}

The principle of a pressuremeter test is to introduce a cylindrical probe with a flexible cover membrane which can expand radially in a hole (AFNOR, 2000; ASTM, 2007). The pressuremeter test is realized in 3 steps: (i) the probe inflates to obtain the contact with the wall of the hole, (ii) the volume increases linearly with the increasing pressure allowing the calculation of the pressuremeter modulus $\mathrm{E}_{\mathrm{M}}$ (the soil pseudo-elastic reaction versus the probe pressure) and (iii) the large displacements take place and the soil becomes plastic. The creep pressure, $\mathrm{p}_{\mathrm{f}}$ is the boundary between the second and the third steps of the test. The limit pressure $p_{1}$ is the measured pressure when the injected volume reaches twice the original volume of the cavity.

Only six mini-pressuremeter tests were performed in each massif to prevent edge effects and cross-influence between the tests. The test points were positioned on a concentric circle with a diameter half that of the container (Figure 3). All the test points were located at the same radial position to allow a comparison of the results. The pressuremeter tests were conducted with an APAGEO® mini-pressuremeter probe of $380 \mathrm{~mm}$ in height and $28 \mathrm{~mm}$ in diameter. Before each pressuremeter test, a core with a diameter equal to that of the mini-pressuremeter probe was extracted using a core sampler. The 630-mm-length core was divided into small pieces to measure the water content and density of the material as a function of depth. The center of the probe was positioned halfway along the height of the compacted soil $(385 \mathrm{~mm})$. The probe was connected to a GDS ${ }^{\circledR}$ pressure-volume controller. The pressure controlled test consisted in applying increasing pressure with equal increments of $25 \mathrm{kPa}$ for at least one minute per step. The equilibrium volume was measured for each increment and the volume was plotted as a function of pressure. The test was stopped when the injected volume (i.e., the volume variation limit of the probe) reached $140,000 \mathrm{~mm}^{3}$. Immediately after the pressuremeter test at a given temperature, the borehole was filled with the same material, at the same water content, to avoid influencing the later tests. The effect of temperature variations on the resistance of the mini-pressuremeter membrane was measured by 
placing the probe in a climatic chamber at a given temperature during the calibration test of the membrane resistance.

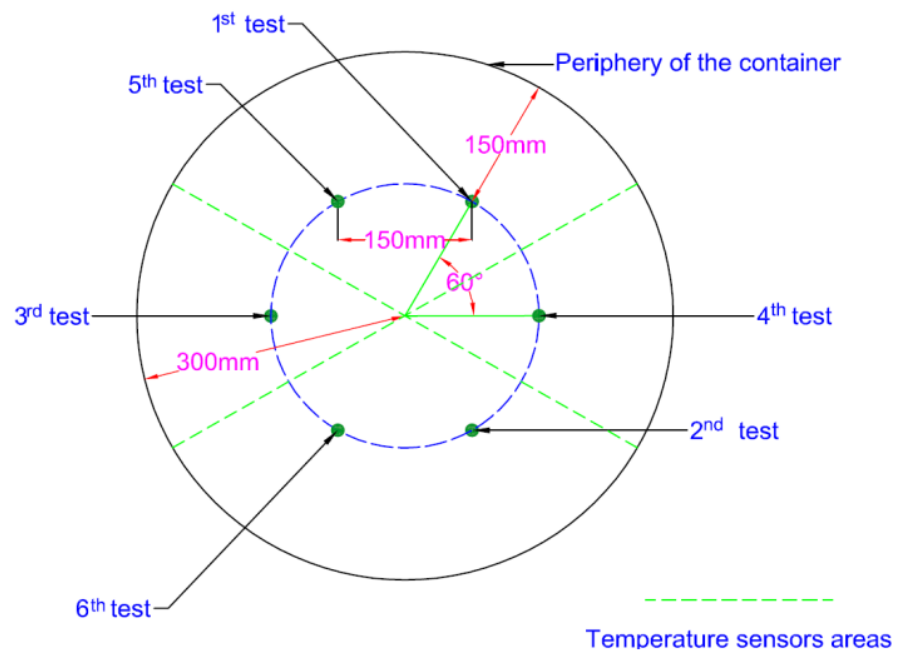

FIG. 3. Positions of the test points.

\section{RESULTS}

In the framework of this study, a preliminary series and four test series, with six minipressuremeter tests for each series, were conducted. In this paper only the two last test series, which aimed to quantify the effect of a cyclic thermal variation on the pressuremeter parameters, are presented. The tests performed on each sample were numbered as "Xx", where $\mathrm{X}$ is the massif temperature used in the test (i.e., 1, 20 or $40{ }^{\circ} \mathrm{C}$ ) and $\mathrm{x}$ is a letter indexing the test that increments for each new test conducted at the same temperature.

The results of the preliminary test series indicated that the tests had good repeatability and facilitated the estimation of the uncertainty of each parameter according to the Student's t-distribution (because of the limited number of measurements) for a $90 \%$ confidence interval: $E_{p}: \pm 10 \%, p_{f}: \pm 5 \%, p_{l}: \pm 5 \%$.

The selected test series, named series I and series II, consisted in tests at 20,1 and $40{ }^{\circ} \mathrm{C}$. The initial temperature of the massif was $20^{\circ} \mathrm{C}$ and the massif was successively brought to 1 and $40{ }^{\circ} \mathrm{C}$, each step lasted at least 70 hours (Figure 4 and Figure 5). The thermal equilibrium was reached for each step before performing the mini-pressuremeter test.

Table 1 and Table 2 present all the obtained parameters and properties. The average water content and the average dry density variations according to the temperature change were lower than 1\%: the massifs were homogeneous.

The mini-pressuremeter tests were conducted at the end of the selected steps as shown in the Figure 4 and Figure 5. The pressuremeter curves (Figure 6) were consistent with the classical pressuremeter results. Considering the length of the $2^{\text {nd }}$ step of the pressuremeetr curve, one can conclude that a softening occurred upon heating to $40{ }^{\circ} \mathrm{C}$ and a hardening was observed upon cooling to $1{ }^{\circ} \mathrm{C}$, regardless of testing order. 


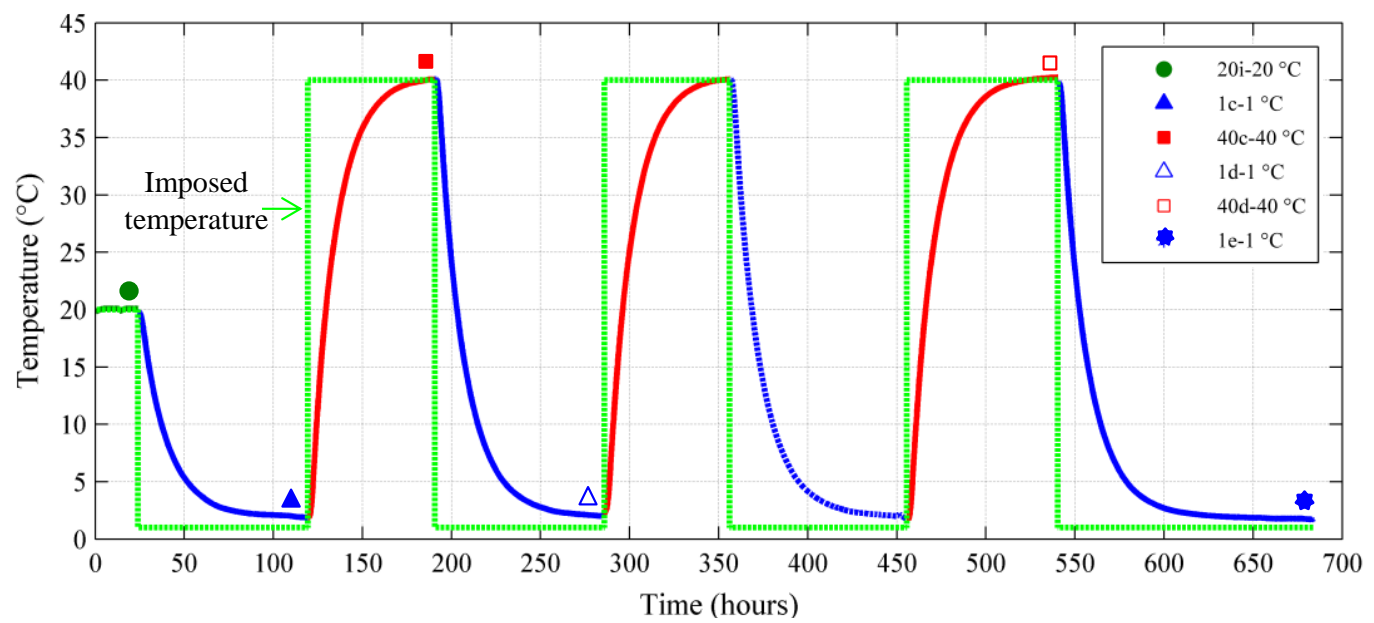

FIG. 4. Temperature variation at $150 \mathrm{~mm}$ from the edge of the massif (lines) and the chronology of the pressuremeter tests (points) for series I.

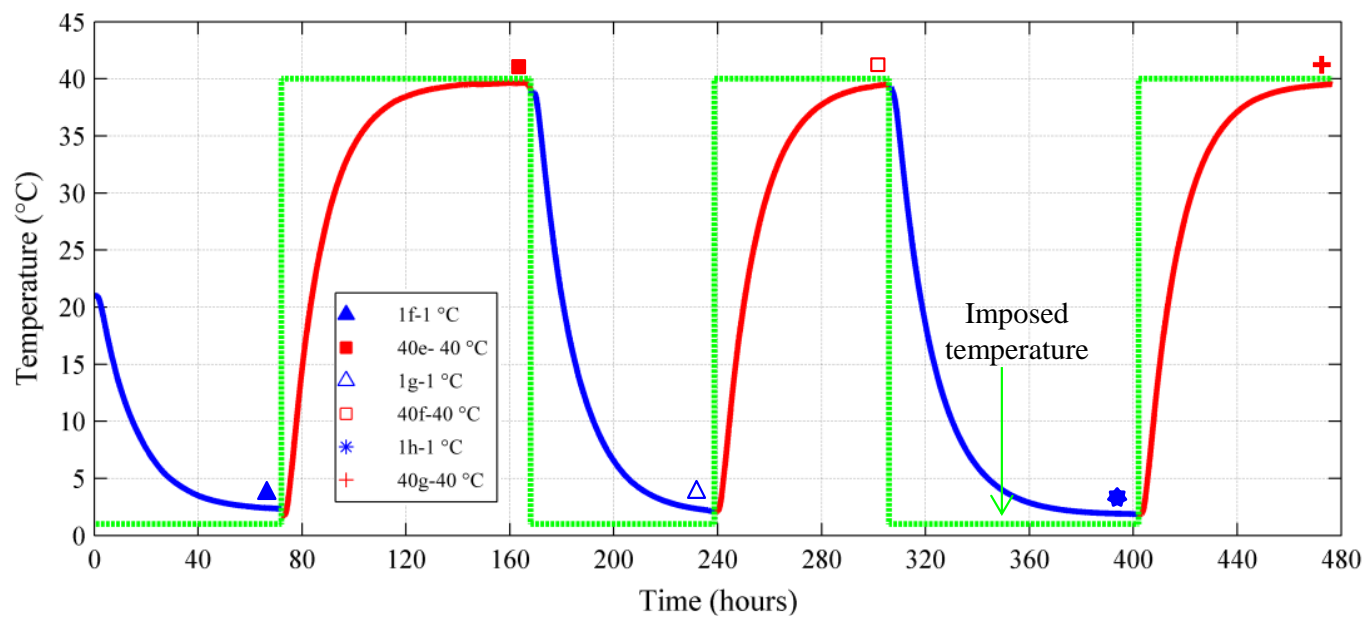

FIG. 5. Temperature variation at $150 \mathrm{~mm}$ from the edge of the massif and the chronology of the pressuremeter tests (points) for series II.

Table 1. Pressuremeter parameters for the series I: temperature cycling (201-40-1-40-1-40-1 ${ }^{\circ} \mathrm{C}$ ).

\begin{tabular}{|c|c|c|c|c|c|c|}
\hline Test & $\begin{array}{c}\text { Temperature } \\
\left({ }^{\circ} \mathbf{C}\right)\end{array}$ & $w(\%)$ & $\rho_{\boldsymbol{d}}\left(\mathbf{M g} / \mathbf{m}^{\mathbf{3}}\right)$ & $\boldsymbol{p}_{\boldsymbol{f}}(\mathbf{k P a})$ & $\boldsymbol{p}_{\boldsymbol{l}}(\mathbf{k P a})$ & $E_{\boldsymbol{p}}(\mathbf{M P a})$ \\
\hline 20i & 20 & 31.4 & 1.25 & 103 & 240 & 5.51 \\
\hline 1c & 1 & 31.4 & 1.26 & 124 & 303 & 5.73 \\
\hline 40c & 40 & 32.1 & 1.25 & 125 & 236 & 7.68 \\
\hline 1d & 1 & 31.7 & 1.25 & 123 & 337 & 4.16 \\
\hline 40d & 40 & 31.5 & 1.28 & 143 & 270 & 6.85 \\
\hline 1e & 1 & 31.6 & 1.24 & 133 & 310 & 5.66 \\
\hline
\end{tabular}


Table 2. Pressuremeter parameters for the series II: temperature cycling (201-40-1-40-1-40 $\left.{ }^{\circ} \mathrm{C}\right)$.

\begin{tabular}{|c|c|c|c|c|c|c|}
\hline Test & $\begin{array}{c}\text { Temperature } \\
\left({ }^{\circ} \mathbf{C}\right)\end{array}$ & $\boldsymbol{w}(\boldsymbol{\%})$ & $\boldsymbol{\rho}_{\boldsymbol{d}}\left(\mathbf{M g} / \mathbf{m}^{\mathbf{3}}\right)$ & $\boldsymbol{p}_{\boldsymbol{f}}(\mathbf{k P a})$ & $\boldsymbol{p}_{\boldsymbol{l}}(\mathbf{k P a})$ & $\boldsymbol{E}_{\boldsymbol{p}}(\mathbf{M P a})$ \\
\hline $40 \mathrm{e}$ & 40 & 31.2 & 1.30 & 174 & 305 & 6.24 \\
\hline $1 \mathrm{~g}$ & 1 & 31.5 & 1.24 & 170 & 357 & 6.97 \\
\hline $40 \mathrm{f}$ & 40 & 31.2 & 1.28 & 170 & 307 & 6.18 \\
\hline $1 \mathrm{~h}$ & 1 & 31.0 & 1.24 & 160 & 344 & 6.16 \\
\hline $40 \mathrm{~g}$ & 40 & 31.1 & 1.25 & 153 & 276 & 5.76 \\
\hline
\end{tabular}
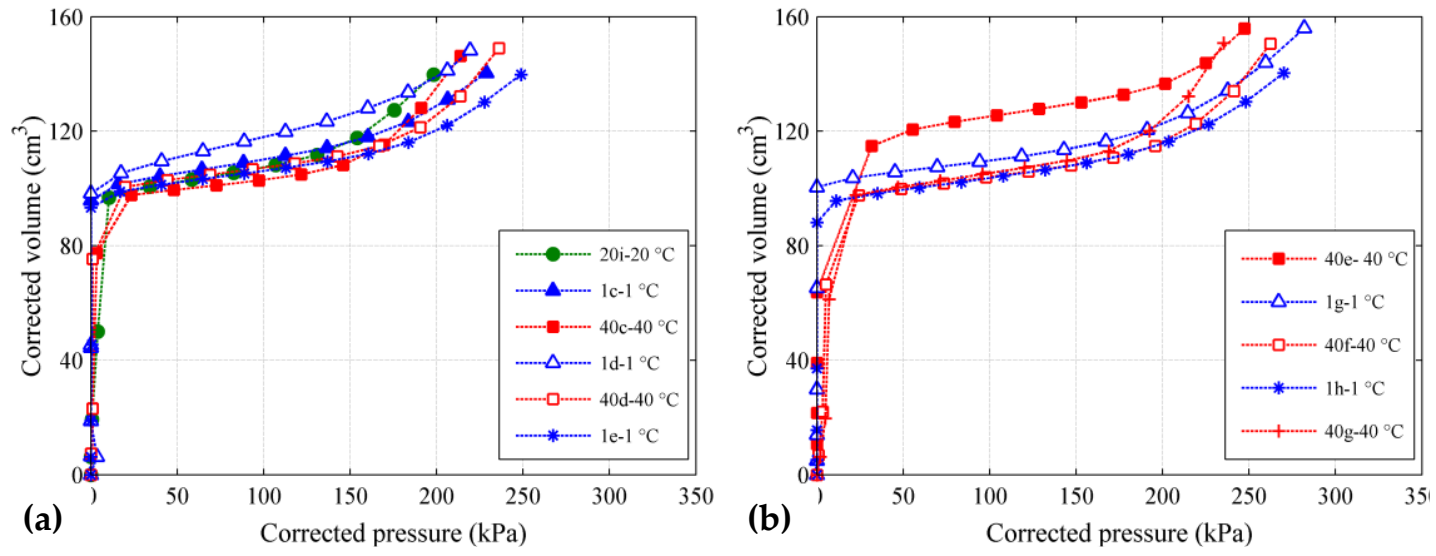

FIG. 6. Pressuremeter curves: (a) series I; (b) series II.

The pressuremeter parameters were calculated for each step of each series and presented in Figure 7. In series I, $p_{f}$ increased slightly with cooling the massif from 20 to $1{ }^{\circ} \mathrm{C}$, The value of $p_{f}$ then remained nearly constant over the subsequent heating/cooling cycles (140-1 $\left.{ }^{\circ} \mathrm{C}\right)$. The $p_{l}$ values increased with heating and decreased with cooling. In series II, the first value at $20^{\circ} \mathrm{C}$ was invalid; in Figure 7, the corresponding values were estimated by assuming similarity between series I and series II.

The parameters evolutions from these two series are comparable. After the first thermal cycle, the variation of $p_{f}$ with temperature decreased within the parameter uncertainty domain, and this parameter reached a stable value (Figure 7a, b). Meanwhile, the evolution of $p_{l}$ differed from that of $p_{f}$. The temperature impact remained measurable as well as completely reversible. Its change rate could be estimated at $1.5 \mathrm{kPa} /{ }^{\circ} \mathrm{C}$ in the studied temperature range $\left(1-40{ }^{\circ} \mathrm{C}\right)$ (Figure $\left.7 \mathrm{c}, \mathrm{d}\right)$. These results are consistent with the contraction of the elastic domain (yield locus) with increasing temperature shown in the literature with oedometer or triaxial tests for various clay materials (Hueckel and Baldi 1990; Tanaka et al., 1997; Graham et al., 2001; Cekerevac and Laloui 2004; Marques et al., 2004; Uchaipichat and Khalili 2009).

The variation of $E_{p}$ with temperature was lower than the other pressuremeter parameters 
(Figure 7e, f). The $E_{p}$ evolution for series I was erratic. In contrast, a slight $E_{p}$ decrease, which was consistent with the previous tests, was measured when the massif was heated.
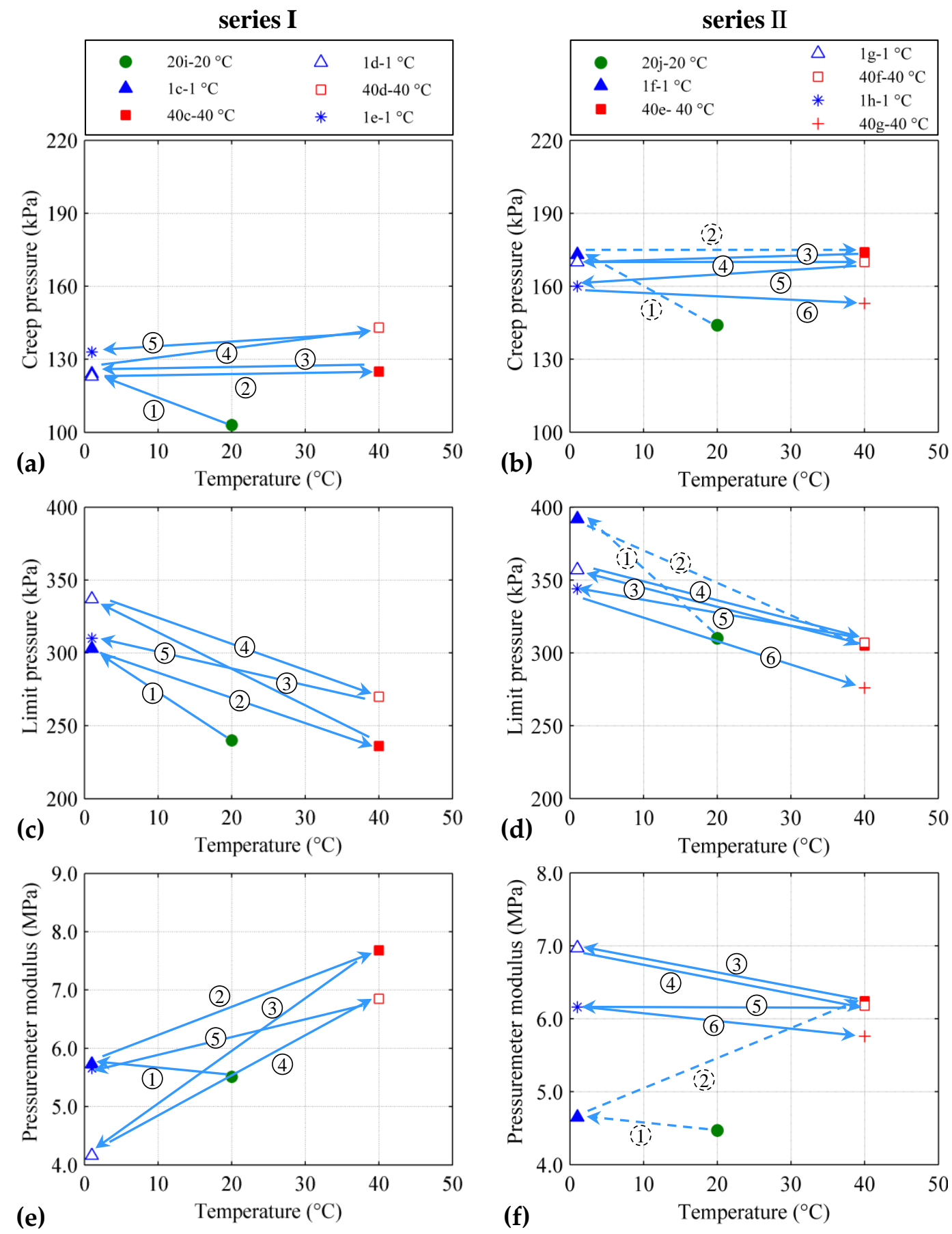

Figure 7. Variation of creep pressure $\left(p_{f}\right)(a-b)$, limit pressure $\left(p_{l}\right)(c-d)$ and pressuremeter modulus $\left(E_{p}\right)(e-f)$ with temperature for series I and II. Dotted lines correspond to estimated parameters. 


\section{CONCLUSIONS}

The objective of this paper was to quantify the effect of cyclic temperature variations on parameters linked to the pile design. A protocol allowing the realization of minipressuremeter test in laboratory conditions was developed. The evolution of the pressuremeter modulus $\left(E_{p}\right)$, the creep pressure $\left(p_{f}\right)$ and the limit pressure $\left(p_{l}\right)$ was measured under imposed thermal conditions on a clayey compacted soil selected for its high sensitivity to temperature variations.

The results of the mini-pressuremeter tests on the compacted illitic soil showed a decrease in the creep pressure and the limit pressure as temperature increased (thermal softening), while the variation of the pressuremeter modulus was less significant, possibly due to the variability of this parameter, which is known to be high. For the following cycles, the effect of the temperature variation was lower. After more than one cycle, $p_{f}$ seemed to reach an equilibrium value independent of the temperature. The $p_{l}$ kept its temperature dependence beyond the $1^{\text {st }}$ cycle but its evolution was reversible and the evolution rate was $1.5 \mathrm{kPa} /{ }^{\circ} \mathrm{C}$ in the studied temperature range $\left(1-40{ }^{\circ} \mathrm{C}\right)$.

The limit pressure is the key parameter in the calculation of the ultimate load of piles. Therefore, the variation of the limit pressure with temperature should be considered when estimating the bearing capacity of geothermal piles, particularly when constructed in temperature-sensitive soils.

\section{ACKNOWLEDGEMENTS}

This study was part of the GECKO research program funded by ANR.

\section{REFERENCES}

AFNOR, NF P94-051 (1993). "Soil : investigation and testing. Determination of Atterberg's limits. Liquid limit test using cassagrande apparatus. Plastic limit test on rolled thread." Paris, France: Association Française de Normalisation, p. 15.

AFNOR, NF P94-093 (1999). "Soils : investigation and testing - Determination of the compaction reference values of a soil type - Standard proctor test - Modified proctor test." Paris, France: Association Française de Normalisation, p. 18.

AFNOR, NF P94-110-1 (2000). "Soil : investigation and testing - Menard pressure meter test - Part 1 : test without unload-reload cycle." Paris, France: Association Française de Normalisation, p. 42.

AFNOR, NF P94-262 (2012). "Justification of geotechnical work - National application standards for the implementation of Eurocode 7 - Deep foundations." Paris, France: Association Française de Normalisation, p. 206.

ASTM D4719-07 (2007). "Standard Test Methods for Prebored Pressuremeter Testing in Soils." ASTM International, West Conshohocken, PA www. ASTM. org, p. 10.

Akrouch, G. A., Sánchez, M., and Briaud, J. L. (2014). "Thermo-mechanical behavior of 
energy piles in high plasticity clays." Acta Geotechnica, Vol. 9(3): 399-412.

Bourne-Webb, P. J., Amatya, B., Soga, K., Amis, T., Davidson, C., and Payne, P. (2009). "Energy pile test at Lambeth College, London: geotechnical and thermodynamic aspects of pile response to heat cycles." Géotechnique, Vol. 59 (3): 237-248.

Bourne-Webb, P. J., Soga K., and Amatya, B. (2013). "A framework for understanding energy pile behaviour." Geotech. Eng., Vol. 166 (2): 170-177.

Cekerevac, C., and Laloui, L. (2004). "Experimental study of thermal effects on the mechanical behaviour of a clay." Int. J. Numer. Anal. Methods Geomech., Vol. 28(3): 209-228.

Eslami, H., Rosin-Paumier, S., Abdallah, A., and Masrouri, F. (2015). "Impact of temperature variation on penetration test parameters in compacted soils." Eur. J. Environ. Civ. Eng., Vol. 19(5): 628-648.

Graham, J., Tanaka, N., Crilly, T., and Alfaro, M. (2001). "Modified Cam-Clay modelling of temperature effects in clays." Can. Geotech. J., Vol. 38(3): 608-621.

Hueckel, T., and Baldi, G. (1990). "Thermoplasticity of saturated clays: experimental constitutive study." J. Geotech. Eng., Vol. 116(12): 1778-1796.

Knellwolf, C., Peron, H. and Laloui, L. (2011). "Geotechnical Analysis of Heat Exchanger Piles.” J. Geotech. \& Geoenv. Eng., Vol 137(10): 890-902

Laloui, L., Moreni, M., and Vulliet, L. (2003). "Comportement d'un pieu bi-fonction, fondation et échangeur de chaleur." Can. Geotech. J., Vol. 40(2): 388-402.

Marques, M. E. S., Leroueil, S., and Soares de Almeida, M. D. S. (2004). "Viscous behaviour of St-Roch-de-1'Achigan clay, Quebec." Can. Geotech. J., Vol. 41(1): 2538.

Murphy, K. D.,. McCartney, J. S. (2015). "Seasonal response of energy foundations during building operation." Geotech Geol Eng. Vol 33: 343-356.

Olgun, C. G., Ozudogru, T. Y., and Arson, C. F. (2014). "Thermo-mechanical radial expansion of heat exchanger piles and possible effects on contact pressures at pilesoil interface" Geotech. Lett., Vol. 4: 170-178.Stewart, M.A., and McCartney, J.S. (2013). "Centrifuge Modeling of Soil-Structure Interaction in Energy Foundations." J. Geotech. \& Geoenv. Eng., Vol 140(4).

Tanaka, N., Graham, J., and Crilly, T. (1997). "Stress-strain behaviour of reconstituted illitic clay at different temperatures." Eng. Geol., Vol. 47(4): 339-350.

Tang, A. M., Pereira, J. M., Hassen, G., and Yavari, N. (2013). "Behavior of HeatExchanger Piles from Physical Modeling." Energy Geostructures, 79-97.

Uchaipichat, A., and Khalili, N. (2009). "Experimental investigation of thermo-hydromechanical behaviour of an unsaturated silt." Géotechnique, vol. 59(4): 339-353. 